\title{
Keragaman Genetik Bawang Merah (Allium cepa L.) Berdasarkan Marka Morfologi dan ISSR
}

\section{Genetic Diversity of Shallot (ㅅllium cepa L.) Based on Morphological and ISSR Markers}

\author{
Vebrita Sari' ${ }^{1}$, Miftahudin ${ }^{2}$, dan Sobir ${ }^{3,4^{*}}$ \\ 'Program Studi Biologi Tumbuhan, Sekolah Pascasarjana, Institut Pertanian Bogor \\ ${ }^{2}$ Departemen Biologi, Fakultas Matematika dan Ilmu Pengetahuan Alam, Institut Pertanian Bogor \\ (Bogor Agricultural University), Jl. Meranti, Kampus IPB Dramaga, Bogor 16680 \\ ${ }^{3}$ Departemen Agronomi dan Hortikultura, Fakultas Pertanian, Institut Pertanian Bogor \\ (Bogor Agricultural University), Jl. Meranti, Kampus IPB Darmaga, Bogor 16680, Indonesia \\ ${ }^{4}$ Pusat Kajian Hortikultura Tropika, Kampus IPB Baranangsiang, Bogor, Indonesia
}

Diterima 11 Mei 2016/Disetujui 12 Oktober 2016

\begin{abstract}
Development of new shallot varieties requires genetic variation of the germplasm. However, information on genetic diversity of local shallot in Indonesia is still lacking. This study was aimed to analyze the genetic diversity of shallot based on morphological characters and ISSR markers for management of genetic resource and breeding program in Indonesia. This study was conducted during October 2014 to September 2015. The 34-shallot genotypes were collected from several regions in Indonesia in the form of the bulb. Twenty four morphological markers and 13 ISSR primers were used in this research. The informative characters to analyze genetic diversity of shallot were foliage cracking, bulb number and bulb morphological characters. ISSR markers generated 103 DNA polymorphic band with the total of $89.57 \%$ and the informative primers were ISSRred 4, ISSRred 9 and ISSRred 20. Both morphological and ISSR markers showed 27\% genetic diversity and grouped all genotypes into two main groups; however the grouping did not relate to the geographic origin. The largest bulb diameter of $7.54 \mathrm{~cm}$ was obtained from Bangkok variety and the highest number of bulb per clump of 27 bulb/clump was produced by the genotype from Pekanbaru. These genotypes can be used as potential parents for shallot breeding program in Indonesia.
\end{abstract}

Keywords: genetic diversity, ISSR markers, morphological characters, shallot

\section{ABSTRAK}

Pengembangan varietas bawang merah membutuhkan variasi genetik dari plasma nutfah bawang merah. Namun, informasi tentang keragaman genetik bawang merah lokal Indonesia masih terbatas. Penelitian ini bertujuan untuk menganalisis keragaman genetik dari 34 genotipe bawang merah koleksi Pusat Kajian Hortikultura Tropika Institut Pertanian Bogor (PKHT-IPB) berdasarkan marka morfologi dan ISSR. Hasil penelitian ini diharapkan dapat dijadikan informasi dasar dalam pengelolaan sumber daya genetik dan pemuliaan bibit unggul bawang merah di Indonesia. Penelitian ini dilaksanakan pada bulan Oktober 2014 sampai dengan September 2015. Sebanyak 34 genotipe bawang merah yang berupa umbi dikoleksi dari beberapa daerah di Indonesia. Sejumlah 24 karakter morfologi dan 13 primer ISSR digunakan dalam penelitian ini. Dendrogram dan PCA dikonstruksi menggunakan program NTSys. Karakter informatif untuk menganalisis keragaman morfologi bawang merah antara lain: tingkat kepatahan daun, jumlah siung umbi dan morfologi pada umbi. Marka ISSR menghasilkan 103 pita DNA polimorfik dengan persentase polimorfik total sebesar 89.57\% dan primer informatif yang didapat: ISSRred 4, ISSRred 9 dan ISSRred 20. Keseluruhan genotipe, baik berdasarkan marka morfologi maupun marka ISSR menghasilkan dua kelompok utama dengan keragaman genetik sebesar 27\%, namun pengelompokan tidak berhubungan dengan asal geografi genotipe tersebut. Genotipe bawang merah yang dikategorikan unggul diantaranya genotipe dengan diameter umbi terbesar yaitu varietas Bangkok $(7.54 \mathrm{~cm})$ dan genotipe yang memiliki jumlah siung umbi terbanyak yaitu genotipe asal Pekanbaru (27 siung/rumpun). Genotipe tersebut dapat dijadikan sebagai genotipe tetua yang potensial dalam merakit varietas unggul bawang merah Indonesia.

Kata kunci: karakter morfologi, marka ISSR, shallot

\footnotetext{
* Penulis untuk korespondensi. e-mail: ridwanisobir@gmail.com
} 


\section{PENDAHULUAN}

Bawang merah (Allium cepa L.) merupakan salah satu tanaman hortikultura yang populer dalam dunia kuliner, sebagai bumbu masakan (flavor), sayuran (acar dan salad) dan produk olahan (bawang goreng), saat ini ekstrak umbi bawang merah sedang dipelajari sebagai obat tradisional (antimicrobial, anticancer dan anti-inflammatory) (Shinkafi dan Dauda, 2013; Motlagh et al., 2011). Peningkatan penduduk dan penurunan luas lahan penanaman menuntut tersedianya varietas baru yang berdaya hasil tinggi. Perakitan varietas unggul membutuhkan sumber daya genetik yang tinggi terkait sifat-sifat yang diinginkan.

Analisis keragaman genetik dari setiap sumber daya genetik yang tersedia perlu dilakukan untuk mendapatkan data deskripsi atau karakter spesifik dari masing-masing genotipe baik secara morfologi maupun molekuler. Informasi keragaman genetik diperlukan untuk mengetahui kemiripan atau jarak genetik antar genotipe. Jarak genetik inilah yang dapat digunakan sebagai dasar untuk menentukan genotipe tetua yang akan digunakan dalam proses pemuliaan bawang merah. Persilangan antar genotipe yang memiliki jarak genotipe terjauh akan memberikan hasil terbaik pada program pemuliaan tanaman menyerbuk silang seperti bawang merah (Degewione et al., 2011).

Budidaya bawang merah yang telah berlangsung lama dengan kondisi agroekosistem Indonesia yang beragam dapat menyebabkan tingginya keragaman genetik bawang merah sehingga melahirkan varietas-varietas lokal. Indonesia memiliki banyak varietas lokal bawang merah sebagai sumber plasma nutfah yang penting untuk tujuan pemuliaan varietas unggul dan pemilihan genotipe penting yang akan dikonservasi. Namun penelitian dan informasi tentang keragaman genetik bawang merah lokal Indonesia masih terbatas, untuk itu perlu dilakukan penelitian tentang keragaman genetik pada tanaman bawang merah.

Keragaman genetik bawang merah dapat dianalisis menggunakan marka morfologi dan molekuler. Marka morfologi merupakan karakter yang paling cepat dan mudah diamati. Namun, karakter morfologi merupakan hasil interaksi gen dan lingkungan sehingga marka morfologi memiliki keterbatasan yaitu bersifat tidak konsisten karena dipengaruhi oleh faktor lingkungan. Keterbatasan tersebut dapat diatasi dengan penggunaan marka molekuler yang berbasis DNA. Marka DNA yang bersifat lebih konsisten dan memiliki tingkat akurasi cukup tinggi salah satunya adalah Inter Simple Sequences Repeat (ISSR) yang dikembangkan dari wilayah mikrosatelit (Moulin et al., 2012).

ISSR merupakan daerah bukan gen yang tidak mengkode protein (non coding region) dan berada diantara dua lokus mikrosatelit. Marka ISSR menggunakan primer tunggal yang pada bagian ujung 3' dan 5' terdapat penambahan sekuen nukleotida (Adeyose et al., 2012; Akter et al., 2015). Keunggulan ISSR antara lain: tidak dipengaruhi oleh kondisi lingkungan dan musim, tidak membutuhkan informasi sekuen terlebih dahulu, berbasis Polymerase Chain Reaction (PCR), DNA cetakan yang digunakan lebih sedikit (5-50 ng per reaksi), wilayah sekuen tersebar diseluruh genom sehingga menghasilkan pola polimorfisme lebih tinggi dibandingkan dengan teknik Random Amplified Polymorphic DNA (RAPD) dan dapat diaplikasi pada tingkat spesies (Son et al., 2012; Riupassa et al., 2015; Sulassih et al., 2013). Penelitian ini bertujuan untuk menganalisis keragaman genetik tanaman bawang merah menggunakan marka morfologi dan ISSR yang diharapkan dapat dijadikan informasi dasar dalam pengelolaan sumber daya genetik dan perakitan bibit unggul bawang merah.

\section{BAHAN DAN METODE}

Penelitian dilaksanakan pada bulan Oktober 2014 sampai dengan September 2015. Penanaman bawang merah di Kebun Percobaan IPB Pasir Sarongge dan analisis data morfologi dan molekuler (ISSR) dilakukan di Laboratorium Molekuler Pusat Kajian Hortikultura Tropika (PKHT) IPB Baranangsiang.

Bawang merah yang digunakan sebanyak 34 genotipe yang berupa umbi. Sampel terdiri dari 25 genotipe merupakan koleksi PKHT dari berbagai daerah di Indonesia dan 9 genotipe merupakan varietas yang telah dilepas Kementrian Pertanian Republik Indonesia (Tabel 1). Penanaman bawang merah menggunakan rancangan acak kelompok lengkap (RAKL) dengan 10 ulangan sampel. Metode penanaman berdasarkan Standar Operasi Prosedur Departeman Pertanian Budidaya Bawang Merah dan pemanenan dilakukan setelah tanaman berumur 60-90 hari (Deptan, 2015).

\section{Analisis Morfologi}

Pengamatan karakter morfologi dan agronomi mengacu pada deskriptor varietas Allium (UPOV, 2008) dengan beberapa modifikasi karakter, sehingga didapatkan 24 karakter morfologi yang diamati. Karakter morfologi yang diamati yaitu: (1) Tinggi tanaman, (2) Bunga: kemampuan berbunga, jumlah bunga dalam karangan, warna mahkota dan anther bunga, (3) Daun; warna, kerapatan, panjang, jumlah helai, lebar dan kepatahan daun, (4) Umbi: bentuk, jumlah siung, warna kulit, ketebalan kulit, diameter, posisi diameter maksimum, lebar leher, warna daging, tinggi, bentuk ujung akar dan batang umbi. Karakter agronomi yaitu: (1) Bobot basah umbi, (2) Umur panen.

\section{Analisis ISSR}

Analisis molekuler 34 genotipe bawang merah menggunakan teknik Inter Simple Sequences Repeat (ISSR). Isolasi DNA total menggunakan metode cetyl trimethyl ammonium bromide (CTAB) oleh Son et al. (2012). Sampel daun muda digerus dengan bantuan pasir kuarsa dan penambahan buffer extract.

Amplifikasi DNA dengan 13 primer ISSR (Tabel 2) menggunakan mesin PCR-GeneAmp merek Applied Biosystems 2720. Setiap primer ISSR-PCR diamplifikasi menggunakan $16 \mu \mathrm{l}$ campuran yang terdiri dari $6 \mu \mathrm{l}$ Go Taq ${ }^{\circledR}$ Green, $1 \mu \mathrm{l}$ primer ISSR, $2.5 \mu \mathrm{l}$ sampel DNA, dan 6 $\mu l$ air bebas ion. Proses PCR dilakukan sebanyak 35 siklus dimana setiap siklus terdiri dari denaturasi awal pada suhu $95{ }^{\circ} \mathrm{C}$ selama 3 menit, denaturasi $93{ }^{\circ} \mathrm{C}$ selama 30 detik, 
Tabel 1. Genotipe bawang merah yang dianalisis

\begin{tabular}{llllll}
\hline No. & Genotipe & \multicolumn{1}{c}{ Asal koleksi } & No. & Genotipe & Asal koleksi \\
\hline 1 & BM_ACH & Aceh & 18 & BM_SL4 & Solo, Jateng \\
2 & BM_BTE & Bantaeng, Sulsel & 19 & BM_SL6 & Solo, Jateng \\
3 & BM_KDR & Kediri, Jatim & 20 & BM_SL7 & Solo, Jateng \\
4 & BM_CRI & Cirebon, Jabar & 21 & BM_SL8 & Solo, Jateng \\
5 & V_Breb & Var. Bima, Brebes, Jateng & 22 & BM_SL9 & Solo, Jateng \\
6 & BM_BLT & Blitar, Jatim & 23 & BM_SLK & Solok, Sumbar \\
7 & BM_BKT & Bukittinggi, Sumbar & 24 & BM_SUM & Sumbawa, NTB \\
8 & V_Kun & Var. Kuning, DIY & 25 & BM_TDY & Koleksi PKHT \\
9 & V_Ilo & Var. Ilokos, Jabar & 26 & V_BGK & Var. Bangkok, Thailand \\
10 & V_Man & Var. Manjung, Jatim & 27 & V_TRS & Var. Trisula, Balitsa \\
11 & V_BtIj & Var. Batu Ijo,Malang & 28 & V_TUK & Var. Tuk-tuk, PT.EWS \\
12 & BM_NJK & Nganjuk, Jatim & 29 & BM_TNG & Rote, Ndao, NTT \\
13 & BM_PKU & Pekanbaru, Riau & 30 & BM_VT1 & Vietnam, Impor \\
14 & V_Sem & Var. Sembrani, Balitsa & 31 & BM_VT2 & Vietnam, Impor \\
15 & BM_SL1 & Solo, Jateng & 32 & BM_VT3 & Vietnam, Impor \\
16 & BM_SL2 & Solo, Jateng & 33 & BM_VT4 & Vietnam, Impor \\
17 & BM_SL3 & Solo, Jateng & 34 & BM_VT5 & Vietnam, Impor \\
\hline
\end{tabular}

Keterangan: Var. $=$ Varietas yang telah dilepas Kementan RI (Dirjen Hortikultura 2012)

penempelan primer (annealing) pada suhu $28-54{ }^{\circ} \mathrm{C}$ selama 45 detik, pemanjangan primer (elongation) pada suhu $72{ }^{\circ} \mathrm{C}$ selama 45 detik dan diakhiri dengan pendinginan pada suhu $72{ }^{\circ} \mathrm{C}$ selama 10 menit. Hasil amplifikasi dielektroforesis dalam gel agarosa $(1.5 \%)$ kemudian direndam di dalam etidium bromida (10\%) dan divisualisasikan dengan sinar UV. Pola pita didokumentasikan menggunakan kamera digital merek Sony Optical Steady-Shot DSC-W730, 16.1 mega pixels 8x optical zoom.

\section{Analisis Data}

Data hasil pengamatan morfologi diterjemahkan ke dalam data multistate (di beri skor bertingkat 1, 2, 3 dan

Tabel 2. Profil pita hasil amplifikasi 13 primer ISSR DNA bawang merah

\begin{tabular}{|c|c|c|c|c|c|c|c|}
\hline No. & Primer & Sekuen & $\begin{array}{c}\text { Suhu } \\
\text { annealing }\end{array}$ & $\begin{array}{l}\text { Ukuran } \\
\text { pita (pb) }\end{array}$ & $\mathrm{JP}$ & JPP & PPP (\%) \\
\hline 1 & PKBT 2 & (AC)8TT & $53^{\circ} \mathrm{C}$ & $250-1500$ & 7 & 6 & 85.71 \\
\hline 2 & PKBT 4 & (AG)8AA & $53^{\circ} \mathrm{C}$ & $250-1500$ & 8 & 8 & 100.00 \\
\hline 3 & PKBT 6 & $(\mathrm{AG}) 8 \mathrm{TT}$ & $53^{\circ} \mathrm{C}$ & $250-2000$ & 9 & 8 & 88.89 \\
\hline 4 & PKBT 7 & (GA)9A & $53^{\circ} \mathrm{C}$ & $250-1500$ & 9 & 8 & 88.89 \\
\hline 5 & РКBT 9 & (GA)9T & $54^{\circ} \mathrm{C}$ & $250-1500$ & 8 & 6 & 75.00 \\
\hline 6 & PKBT 11 & (GT)9C & $54{ }^{\circ} \mathrm{C}$ & $250-1500$ & 8 & 7 & 87.50 \\
\hline 7 & ISSRred 4 & $(\mathrm{CAG}) 6 \mathrm{G}$ & $52{ }^{\circ} \mathrm{C}$ & $250-2000$ & 16 & 15 & 93.75 \\
\hline 8 & ISSRred 7 & $(\mathrm{GTC}) 6$ & $49^{\circ} \mathrm{C}$ & $250-1500$ & 9 & 8 & 88.89 \\
\hline 9 & ISSRred 9 & (CTC)5GC & $51^{\circ} \mathrm{C}$ & $250-2500$ & 12 & 12 & 100.00 \\
\hline 10 & ISSRred 10 & $(\mathrm{CAA}) 5$ & $28^{\circ} \mathrm{C}$ & $250-1500$ & 7 & 7 & 100.00 \\
\hline 11 & ISSRred 17 & $(\mathrm{GAC}) 5$ & $48^{\circ} \mathrm{C}$ & $250-1000$ & 6 & 5 & 83.33 \\
\hline 12 & ISSRred 20 & (TCC) $5 \mathrm{~A}$ & $44{ }^{\circ} \mathrm{C}$ & $250-1000$ & 8 & 7 & 87.50 \\
\hline \multirow[t]{2}{*}{13} & ISSRred 25 & $(\mathrm{CCA}) 6$ & $53^{\circ} \mathrm{C}$ & $250-1500$ & 8 & 6 & 75.00 \\
\hline & Total & & & & 115 & 103 & 89.57 \\
\hline
\end{tabular}

Keterangan: JP $=$ Jumlah pita, JPP $=$ Jumlah pita polimorfik, PPP $=$ Persentase pita polimorfik 
seterusnya) dan pita DNA polimorfik hasil elektroforesis diterjemahkan menjadi data biner yaitu satu (1) apabila terdapat pita pada tingkat migrasi yang sama dan nol (0) apabila tidak terbentuk pita. Pengamatan pita dibantu dengan marker ladder (1 kb promega). Analisis hubungan genetik (dendrogram) dan analisis komponen utama (Principal Components Analysis) menggunakan program Numerical Taxonomy and Multivariate Analisys System (NTSys) versi 2.1.1a.

\section{HASIL DAN PEMBAHASAN}

\section{Keragaman Bawang Merah Berdasarkan Marka Morfologi}

Pengamatan morfologi menghasilkan 19 karakter polimorfik dari 24 karakter yang diamati, dengan persentase polimorfik masing-masing karakter antara 20-100\% dan persentase polimorfik total sebesar 77.08\%. Karakter polimorfik yang dihasilkan dapat menunjukkan adanya keragaman morfologi meskipun genotipe berasal dari spesies yang sama. Keragaman morfologi dapat disebabkan oleh faktor genetik dan lingkungan (Hartati dan Darsana, 2015). Keragaman morfologi antar genotipe merupakan modal awal dalam proses pemuliaan tanaman (Surahman et al., 2009).

Keragaman morfologi yang dimaksud antara lain: umur panen, kemampuan berbunga, tinggi tanaman, warna daun, panjang daun, diameter daun, jumlah daun, tingkat kepatahan daun, bentuk umbi, bentuk ujung batang umbi, bentuk ujung akar umbi, warna daging umbi, warna kulit umbi, diameter umbi, posisi diameter maksimum umbi, lebar leher umbi, tinggi umbi, jumlah siung umbi dan bobot umbi. Umur panen genotipe bawang merah yang diamati berkisar antara 55 hari (varietas Batu Ijo) sampai 90 hari dan sebagian besar genotipe memiliki umur panen kategori sedang (60-90 hari). Secara umum tanaman bawang merah mampu menghasilkan bunga, namun pada penelitian kali ini ditemukan 3 genotipe bawang merah yang tidak mampu menghasilkan bunga yaitu genotipe asal Bukittinggi, Kediri dan varietas Manjung.

Tingkat kepatahan daun, bentuk umbi, bentuk ujung akar umbi dan bentuk ujung batang umbi pada bawang merah yang diamati bervariasi. Jumlah siung umbi yang ditemukan berkisar antara 2 siung (genotiep asal Tanduyung) sampai 27 siung (genotipe asal Pekanbaru). Diameter umbi yang diamati berkisar antara $1.51 \mathrm{~cm}$ (genotipe asal Solo 7) sampai $7.54 \mathrm{~cm}$ (varietas Bangkok). Warna daging umbi yang ditemukan bervariasi yaitu merah keunguan, merah kecoklatan, merah muda, merah tua, ungu keputihan, ungu muda dan ungu tua (Gambar 1).

Bobot basah umbi tertinggi dimiliki oleh varietas Bangkok (57.56 g per rumpun) dan bobot basah umbi terendah dimiliki oleh varietas Kuning ( 2.33 g per rumpun). Menurut Azmi et al. (2011) bawang merah dengan diameter umbi $>1.7 \mathrm{~cm}$ termasuk dalam kategori mutu I yang disenangi konsumen dan petani. Hampir semua genotipe bawang merah yang diamati pada penelitian ini termasuk dalam kategori mutu I yang disenangi oleh konsumen dan petani kecuali genotipe asal Solo $7(1.51 \mathrm{~cm})$ dan varietas
Kuning $(1.56 \mathrm{~cm})$. Keragaman morfologi dan agronomi juga ditemukan pada 49 aksesi bawang merah asal Ethiopia yang memiliki variasi pada karakter tinggi tanaman, panjang daun, diameter umbi, bobot umbi dan umur panen (Degewione et al., 2011). Akter et al. (2015) juga melaporkan 11 genotipe bawang merah asal India memiliki variasi morfologi pada karakter umbi dan daun.

Dendogram berdasarkan ciri morfologi menunjukkan bahwa 34 genotipe bawang merah terbagi menjadi 2 kelompok utama (kelompok I dan II) dengan koefisien kemiripan berkisar antara 0.68-0.95 atau terdapat keragaman ciri morfologi sebesar 0.05-0.32 (27\%). Kelompok I terdiri atas 27 genotipe dimana 18 genotipe merupakan hasil eksplorasi dari berbagai daerah di Indonesia, 5 genotipe berasal dari Vietnam dan 4 genotipe lainnya merupakan varietas yang telah dilepas oleh Kementan RI (Varietas Brebes, Manjung, Kuning dan Trisula). Kelompok II terdiri atas 7 genotipe yaitu Varietas Bangkok (impor), Varietas Batu Ijo, Sembrani, Ilokos, Tuk-Tuk (varietas yang sudah dilepas Kementan RI) dan 2 genotipe hasil eksplorasi (Kediri dan Cirebon) (Gambar 2). Kelompok I mengelompok karena memiliki jumlah siung umbi sedikit (1-4 siung), lebar leher umbi medium, diameter umbi besar ( $>3 \mathrm{~cm})$, bobot umbi sedang (10-20 gr per siung) dan lebar daun $>0.8 \mathrm{~cm}$. Kelompok II berkelompok karena memiliki umur panen $<60$ hari, tinggi tanaman $>30 \mathrm{~cm}$ dan bentuk ujung akar umbi round.

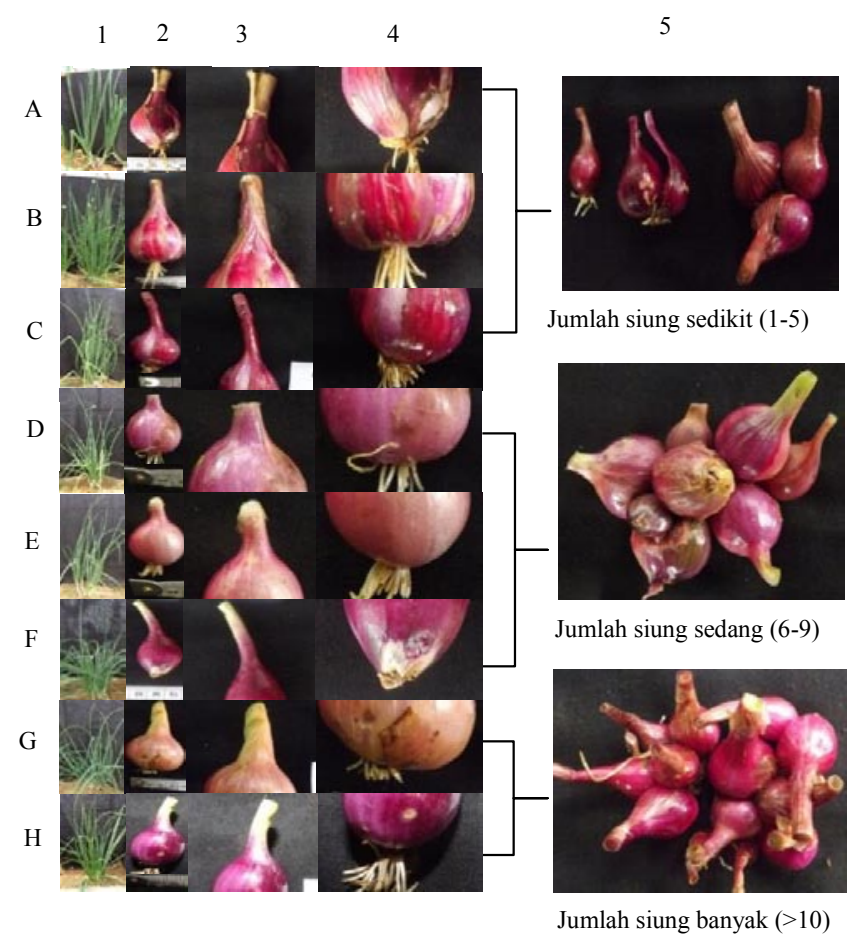

Gambar 1. Variasi morfologi yang ditemukan; tingkat kepatahan daun (1), bentuk dan warna daging umbi (2), shape of root end (bentuk ujung akar umbi) (3) dan shape of stem end (bentuk ujung batang umbi) (4) dan jumlah siung umbi (5). (A) Var. Bangkok, (B) BM BTE, (C) Var. Tuk-Tuk, (D) Var. Brebes, (E) Var. Batu Ijo, (F) Var. Sembrani, (G) Var. Kuning dan (H) Var. Manjung. Var $=$ Varietas; $\mathrm{BM}=$ koleksi PKHT 


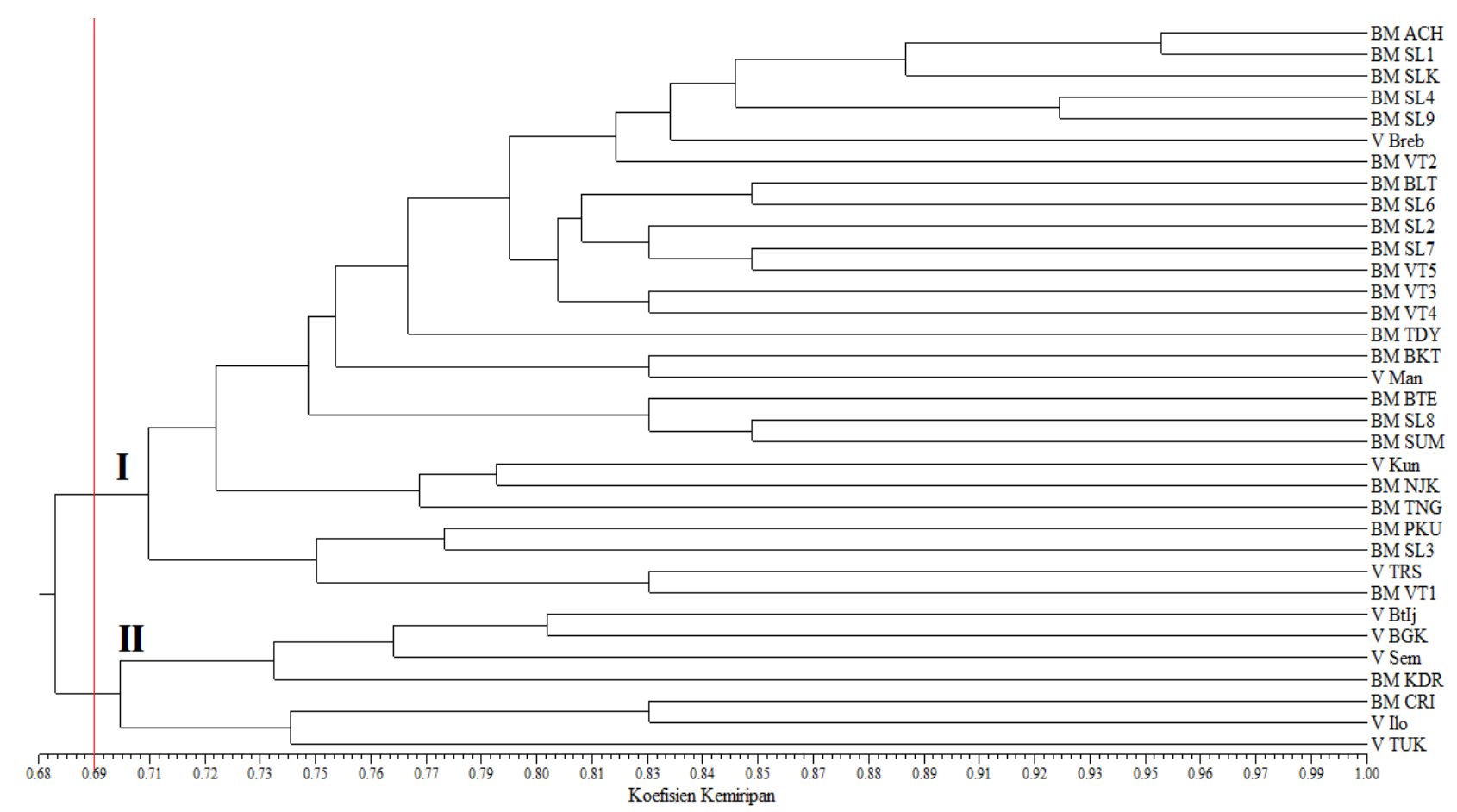

Gambar 2. Dendogram hasil analisis 34 genotipe bawang merah berdasarkan ciri morfologi. $\mathrm{V}=$ Varietas yang sudah dilepas; $\mathrm{BM}=$ Koleksi PKHT

\section{Keragaman Bawang Merah Berdasarkan Marka ISSR}

Primer PKBT dan ISSRred berhasil mengamplifikasi pita DNA dari 34 genotipe bawang merah dengan jumlah dan ukuran pasang basa (pb) yang bervariasi (Tabel 2). Primer yang menghasilkan pola pita polimorfik paling banyak adalah primer ISSRred 4 dan ISSRred 9 yang mampu menghasilkan pita polimorfik masing-masing sebanyak 15 dan 12 pita (Gambar 3), sedangkan pola pita polimorfik paling sedikit dihasilkan dari primer ISSRred 17 yang hanya menghasilkan 5 pita DNA hasil amplifikasi. Persentase pita polimorfik yang dihasilkan dari 13 primer ISSR yaitu 75$100 \%$ dengan persentase polimorfik total sebesar $89.57 \%$. Nilai persentase polimorfik pada penelitian ini sedikit lebih tinggi dibandingkan hasil penelitian Khar et al. (2011) dan Mallor et al. (2014) yaitu polimorfisme masing-masing paling tinggi hanya $75 \%$ pada bawang merah di Spanyol dan di India menggunakan marka Simple Sequence Repeat (SSR).

Dendogram berdasarkan marka ISSR menunjukkan bahwa 34 genotipe bawang merah terbagi menjadi dua kelompok utama (I dan II) dengan nilai koefisien kemiripan genetik berkisar antara 0.62-0.89 atau terdapat keragaman ciri sebesar 0.11-0.38 (27\%) (Gambar 4). Keragaman yang dihasilkan pada penelitian ini sedikit lebih tinggi dibandingkan hasil penelitian Mallor et al. (2014) pada bawang merah di Spanyol menggunakan marka SSR yaitu sebesar 26\%. Kelompok I terdiri atas 30 genotipe dimana 20 genotipe merupakan hasil eksplorasi dari berbagai daerah di Indonesia, 5 genotipe berasal dari Vietnam dan Thailand sedangkan 5 genotipe lainnya merupakan varietas yang telah dilepas oleh Kementan RI (Varietas Bima, Trisula, Tuk-Tuk,

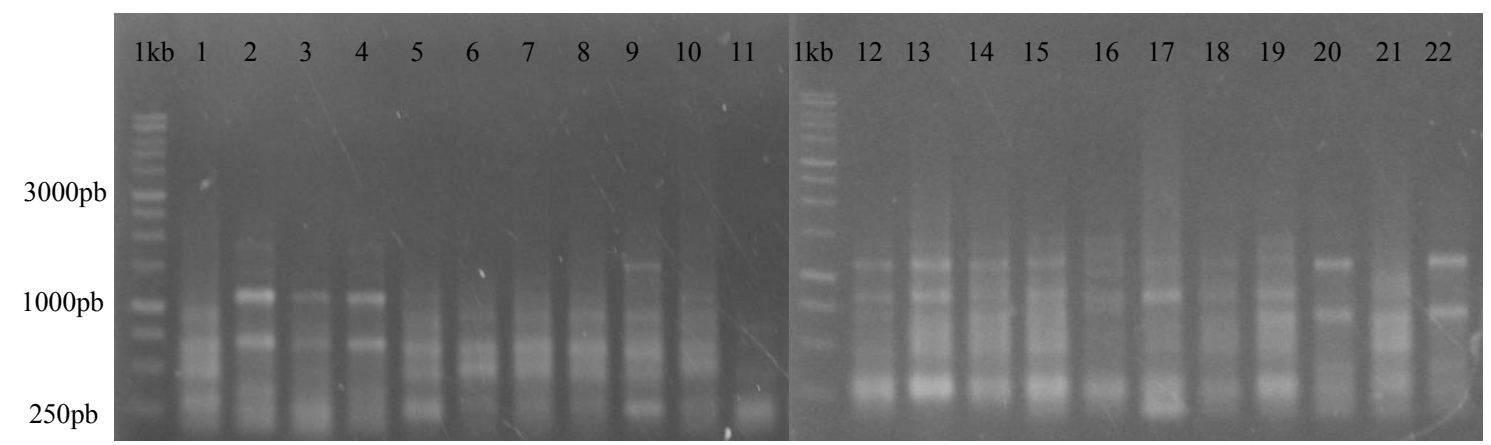

Gambar 3. Hasil amplifikasi Primer ISSRred 4 (CAG)6. (1) BM SL8, (2) BM SL9, (3) Var. Trisula, (4) BM BLT, (5) BM KDR, (6) BM ACH, (7) BM PKU, (8) BM SLK, (9) BM BKT, (10) Var. Brebes, (11) Var. Batu Ijo, (12) Var Sembrani, (13) Var. Bangkok, (14) BM V1, (15) BM V2, (16) BM CRI, (17) BM BTE, (18) BM TDY, (19) BM SL1, (20) BM SL3, (21) BM SL4, (22) BM TNG. Var = Varietas; $\mathrm{BM}=$ Koleksi PKHT 


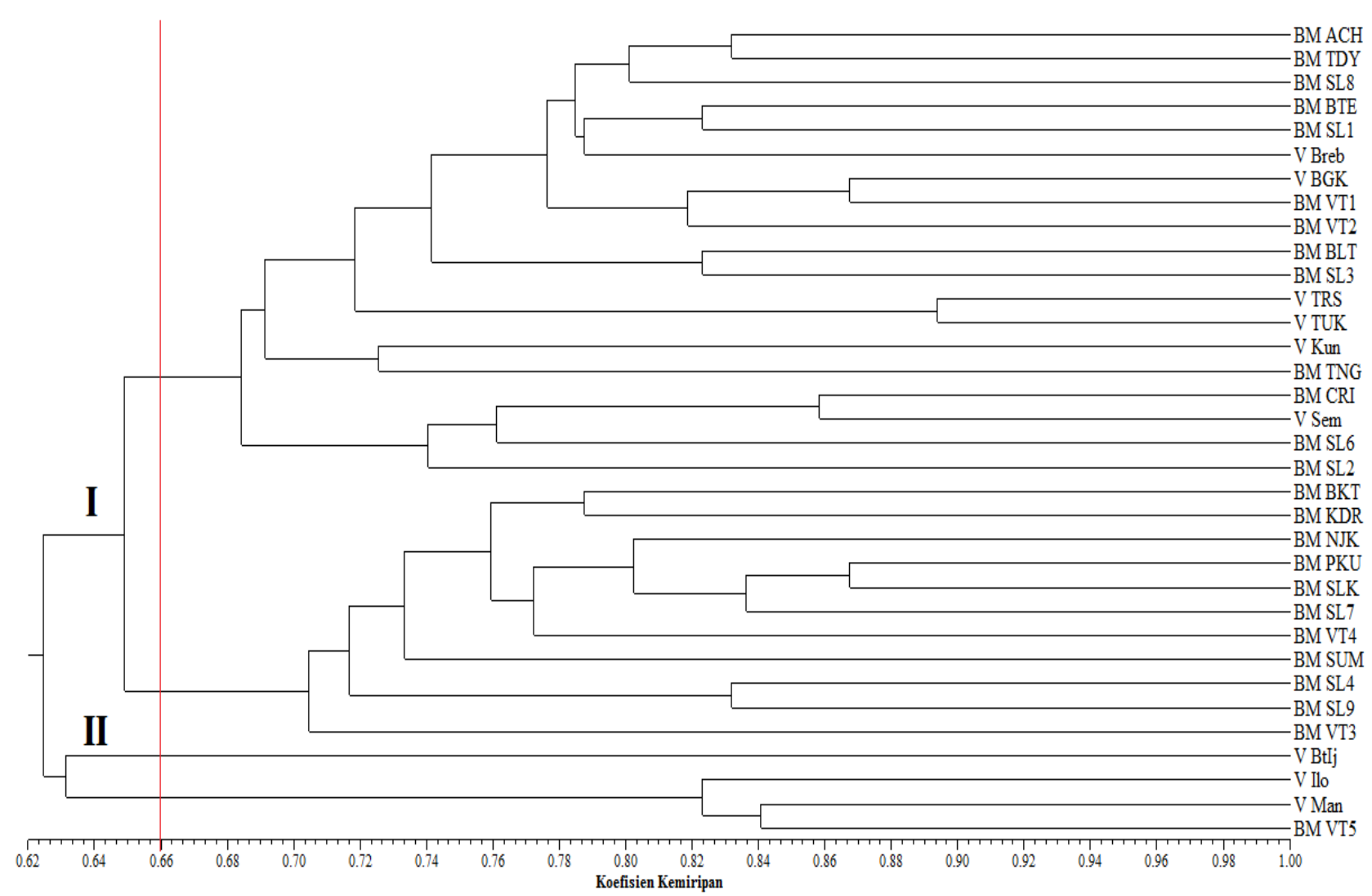

Gambar 4. Dendogram hasil analisis 34 genotipe bawang merah berdasarkan 13 primer ISSR. V = Varietas yang sudah dilepas; BM = Koleksi PKHT

Kuning, dan Sembrani). Kelompok II terdiri atas 4 genotipe yaitu varietas Batu Ijo, Ilokos, Manjung (varietas yang sudah dilepas oleh Kementan RI) dan koleksi bawang merah dari Cirebon (Jawa Barat). Kelompok I mengelompok karena menghasilkan pita pada primer PKBT 2 (250 pb), PKBT $4(750 \mathrm{pb})$, ISSRred 4 (250-750 pb), ISSRred 9 (500 dan $1000-1500 \mathrm{pb})$ dan ISSRred 20 (250-1000 pb) sedangkan kelompok II mengelompok karena menghasilkan pita pada primer PKBT 7 (500-750 pb), ISSRred 4 (750 pb) dan ISSRred 9 (500-750 pb).

Keragaman genetik bawang merah yang dihasilkan pada penelitian ini diduga merupakan hasil proses budidaya dalam waktu lama yang didukung oleh kondisi lingkungan sehingga melahirkan varietas-varietas lokal yang beragam. Pengelompokan 34 genotipe bawang merah yang dianalisis baik menggunakan marka morfologi maupun molekuler (ISSR) terlihat tidak berhubungan dengan asal geografi genotipe melainkan bercampur antara genotipe dari daerah satu dengan daerah lainnya. Hasil penelitian ini sesuai dengan Arifin et al. (2000) yang melaporkan 65 aksesi bawang merah asal Indonesia dan Jepang menggunakan 12 primer RAPD menghasilkan dua kelompok utama yang pengelompokannya tidak berdasarkan asal geografi aksesi bawang merah tersebut.

Pengelompokan 34 genotipe bawang merah pada penelitian ini diduga dipengaruhi oleh distribusi perdagangan bawang merah di Indonesia. Hal ini terlihat dari genotipe yang berkelompok tidak berasal dari geografi yang sama.
Bawang merah yang dikoleksi dari pulau Sumatera (Aceh, Solok, Bukittinggi dan Pekanbaru) berkelompok dengan bawang merah asal pulau Jawa (Blitar, Solo, Tungganamo, Sumbawa, Kediri, Nganjuk, Yogyakarta dan Brebes) juga pulau Sulawesi (Bantaeng). Hal ini terjadi karena petani bawang merah di pulau Sumatera selain menggunakan bibit varietas lokal juga menggunakan bibit yang berasal dari luar wilayah Sumatera. Petani bawang merah di Aceh selain menggunakan bibit dari lokal Aceh juga menggunakan bibit dari Sumatera Utara, sementara itu petani di Sumatera Utara sebagian bibitnya diperoleh dari Jawa Tengah sehingga akhirnya terdapat kemiripan antara genotipe bawang merah yang berasal dari Aceh dengan genotipe bawang merah yang berasal dari Jawa Tengah (Arsanti, 2013; BPS, 2015).

\section{KESIMPULAN}

Marka morfologi menghasilkan 19 karakter informatif dengan koefisien kemiripan berkisar antara 0.68-0.95. Marka ISSR menghasilkan 103 pita DNA polimorfik dari 13 primer dengan koefisien kemiripan berkisar antara 0.62-0.89. Tingkat keragaman genetik yang dihasilkan kedua marka yaitu sebesar 27\%. Pengelompokan yang dihasilkan kedua marka tidak berhubungan dengan asal geografi. Genotipe bawang merah potensial diantaranya: varietas Bangkok (diameter umbi terbesar) dan genotipe asal Pekanbaru (jumlah siung umbi terbanyak). Varietas Bangkok dan Sembrani dapat disilangkan dengan genotipe 
asal Pekanbaru dan Nganjuk karena memiliki jarak genetik cukup jauh. Genotipe tersebut dapat dijadikan genotipe tetua dalam merakit varietas unggul bawang merah Indonesia.

\section{UCAPAN TERIMAKASIH}

Ucapan terimakasih diberikan kepada Direktorat Jenderal Pendidikan Tinggi (DITJEN DIKTI) atas Beasiswa Pendidikan Pascasarjana Dalam Negeri (BPPDN) Calon Dosen 2013 dan riset kerjasama PKHT LPPM-IPB a.n Prof. Dr. Ir. Sobir, M.Si yang telah mendanai penelitian ini.

\section{DAFTAR PUSTAKA}

Adeyose, A.I., O.C. Obi, T.R. Fasola, A.F. Ayodele. 2012. Assessment of genetic diversity in two Allium spp. using Random Amplified Polimorphic DNA (RAPD) markers. J. Med. Plant. Res. 6:4741-4747.

Akter, M.S., A. Biswas, S.S. Siddique, S. Hossain, N. Ivy. 2015. Estimation of genetic diversity in onion (Allium cepa L.). Agriculturists 13:26-34.

Arifin, N.S., Y. Ozaki, H. Okubo. 2000. Genetic diversity in Indonesian shallot (Allium cepa var. ascalonicum) and Allium x wakegi revealed by RAPD markers and origin of Allium $\mathrm{x}$ wakegi dentified by RFLP analysis of amplified chloroplast gene. Euphytica 111:23-31.

Arsanti, I.W. 2013. Supply chains of shallots (Allium ascalonicum L.) in Central Java Indonesia. Acta Hort. 63-70.

Azmi, C., I.M. Hidayat, G. Wiguna. 2011. Pengaruh varietas dan ukuran umbi terhadap produktivitas bawang merah. J. Hort. 21:206-213.

[BPS] Badan Pusat Statistik Indonesia. 2015. Distribusi Perdagangan Komoditas Bawang Merah Indonesia 2015. http://www.bps.go.id [diunduh 13 Februari 2016].

Degewione, A., S. Alamerew, G. Tabor. 2011. Genetic variability and association of bulb yield and related traits in shallot (Allium cepa var aggregatum DON.) in Ethiopia. Inter. J. Agri. Res. 21:1-20.

[Deptan] Departemen Pertanian. 2014. Standard Operasi Prosedur Budidaya Bawang Merah 2015. http://www. deptan.go.id [diunduh 20 September 2014].

Dirjen Hortikultura. 2012. Daftar varietas hortikultura yang telah dilepas oleh Kementan RI tahun 2012. Kementrian Pertanian Indonesia. http://www. drjenhorti.com/ [diunduh 8 april 2014].

Hartati, S., L. Darsana. 2015. Karakterisasi anggrek alam secara morfologi dalam rangka pelestarian plasma nutfah. J. Agron. Indonesia 43:133-139.
Khar, A., K.E. Lawande, K.S. Negi. 2011. Microsatellite marker based analysis of genetic diversity in short day tropical India onion and cross amplification in related Allium spp. Genet. Res. Crop Evol. 58:741752.

Mallor, C., A.M.S. Ardeno, A.C. Garces. 2014. Assessing the genetic diversity of Spanish Allium cepa landraces for onion breeding using microsatellite markers. Sci. Hort. 170:24-31.

Motlagh, H.R., A. Mustafaeie, K. Mansouri. 2011. Anticancer and anti-inflammatory activities of shallot (Allium cepa L.) extract. Arch. Med. Sci. 1:38-44.

Moulin, M.M., R. Rodrigues, L.S.A. Goncalves, C.P. Sudre CP, M.G. Pereira. 2012. A comparison of RAPD and ISSR markers reveals genetic diversity among sweet potato landraces (Ipomoea batatas (L.) Lam.). Acta Sci. Agron. 34:139-147.

Riupassa, P.A., Chikmawati, T., Miftahudin, Suharsono. 2015. The molecular diversity-based ISSR of Durio tanjungpurensis originating from West Kalimantan Indonesia. Makara J. Sci. 19:27-33.

Shinkafi, S.A., H. Dauda. 2013. Antibacterial activity of Allium cepa L. on some pathogenic bacteria associated with ocular infections. J. App. Med. Sci. $1: 147-151$.

Son, J.H., K.C. Park, S. Lee, J.H. Kim, M.S. Kim. 2012. Species relationship among Allium species by ISSR analysis. Hort. Environ. Biothechnol. 53:256-262.

Sulassih. 2011. Analisis hubungan kekerabatan manggis (Garcina mangostana L.) menggunakan penanda morfologi dan molekuler (ISSR) terhadap kerabat dekatnya. Tesis. Sekolah Pascasarjana. Institut Pertanian Bogor. Bogor.

Sulassih, Sobir, E. Santosa. 2013. Phylogenetic analysis of mangosteen (Garcina mangostana L.) and its relatives based on morphological and Inter Simple Sequence Repeat (ISSR) markers. SABRAO J. 45: 478-490.

Surahman, M., E. Santosa, F.N. Misya. 2009. Karakterisasi dan analisis gerombol plasma nutfah jarak pagar Indonesia dan beberapa negara lain menggunakan marka morfologi dan molekuler. J. Agron. Indonesia 37:256-264.

[UPOV] International Union for the Protection of New Varieties of Plants. 2008. Onion, Echalion; Shallot; Grey Shallot, Guidlines for distinctness, uniformity and stability. http://www.upov.int [2 April 2014]. 